\title{
Legitimasi Hak Angket Dewan Perwakilan Rakyat Terhadap Komisi Pemberantasan Korupsi
}

\author{
Muhammad Rinaldy Bima, ${ }^{1}$ Muhammad Kamal, ${ }^{2}$ Hardianto Djanggih ${ }^{3}$ \\ 1Fakultas Hukum Universitas Muslim Indonesia, Makassar, \\ E-mail: muhrinaldy.bima@umi.ac.id \\ 2 Fakultas Hukum Universitas Muslim Indonesia, Makassar, \\ E-mail: kamal.hidjaz@yahoo.co.id \\ ${ }^{3}$ Fakultas Hukum Universitas Tompotika Luwuk Banggai, \\ E-mail: hardianto.djanggih@gmail.com
}

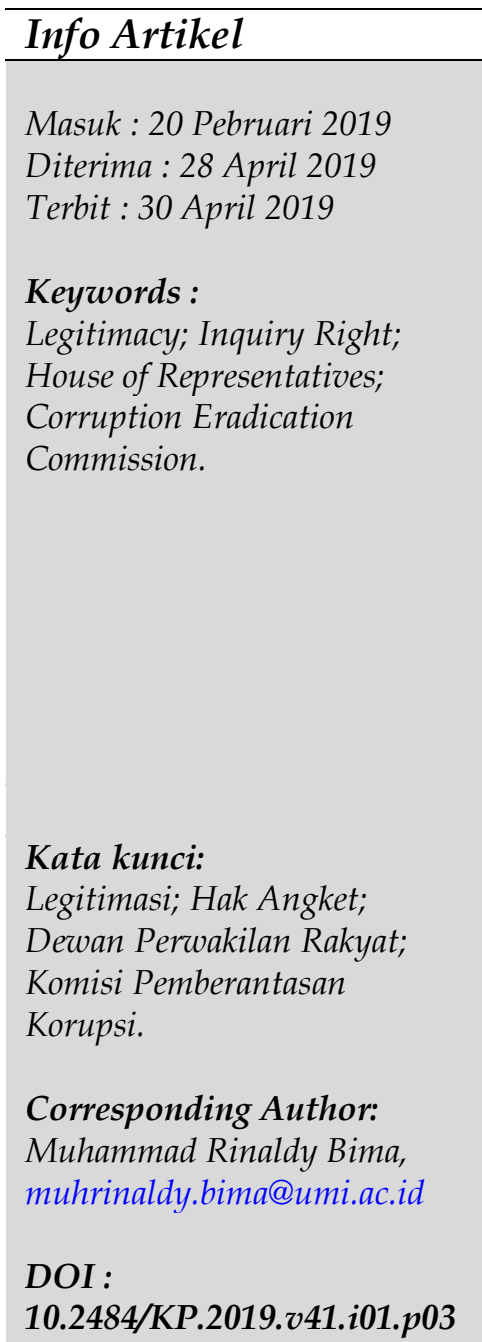

Jurnal Kertha Patrika, Vol. 41, No. 1 April 2019, h. 27-39

\begin{abstract}
This study analyzes the legitimacy of the inquiry right by People's Representatives Council of the Republic of Indonesia, with a focus on the right of inquiry against the Corruption Eradication Commission. It uses a normative legal research that applies statutory approach and conceptual approach. The results of the study indicate that the legitimacy of the People's Representatives Council inquiry rights to the Corruption Eradication Commission is not only based on the decision of the Constitutional Court Number 36 / PUU-XV / 2017, but must fulfill the elements as Article 79 paragraph (3), Article 199 and Article 201 Paragraph (2) of Law Number 17 of 2014. This study suggests the need for various efforts to strengthen the existence of the Corruption Eradication Commission as an independent institution, and free from the influence of any power, given its existence is very important for Indonesia with a high level of corruption.
\end{abstract}

\footnotetext{
Abstrak

Artikel ini menganalisis legitimasi hak angket Dewan Perwakilan Rakyat Republik Indonesia, dengan fokus permasalahan pada hak angket terhadap Komisi Pemberantasan Korupsi (KPK). Penelitian ini menggunakan penelitian yuridis normatif melalui pendekatan perundang-undangan dan pendekatan konseptual. Hasil penelitian menunjukkan bahwa legitimasi hak angket DPR RI terhadap Komisi Pemberantasan Korupsi tidak hanya berdasarkan putusan Mahkamah Konstitusi Nomor 36/PUU-XV/2017, namun harus memenuhi unsurunsur sebagaimana Pasal 79 ayat (3), Pasal 199, dan Pasal 201 Ayat (2) Undang-Undang Nomor 17 Tahun 2014. Rekomendasi dari penelitian ini yakni perlunya berbagai upaya penguatan terhadap eksistensi KPK sebagai lembaga yang independen, serta bebas dari pengaruh kekuasaan manapun, mengingat keberadaan KPK sangat penting bagi Negara Indonesia dengan tingkat korupsi yang masih tinggi.
} 


\section{Pendahuluan}

Hak angket merupakan salah satu hak Dewan Perwakilan Rakyat (DPR) Republik Indonesia yang berfungsi sebagai sarana untuk mewujudkan kedaulatan rakyat dalam Negara Kesatuan Republik Indonesia (NKRI) yang demokratis. Hak angket menjamin adanya checks and balances terhadap lembaga negara yang dibentuk berdasarkan kedaulatan rakyat.

Hak angket DPR diberikan dalam rangka pelaksanaan fungsi pengawasan terhadap cabang kekuasaan lainnya demi terwujudnya kekuasaan yang berimbang. Penggunaan hak angket dilakukan dalam penyelidikan terhadap pelaksanaan undang-undang (UU) atau kebijakan pemerintah yang diduga bertentangan dengan peraturan perundang-undangan. Dalam praktiknya, penggunaan dari hak angket oleh DPR justru banyak memunculkan problema hukum baru di kalangan praktisi hukum tata Negara saat ini. ${ }^{1}$

Sejalan dengan prinsip checks and balances dalam sistem ketatanegaraan Indonesia dianut pula prinsip demokrasi dan prinsip akuntabilitas, yakni adanya pertanggungjawaban dari pihak yang diberi mandat untuk memerintah kepada mereka yang memberi mandat. Dalam hal ini rakyatlah yang memberikan kekuasaan kepada pemerintah untuk memerintah, dan karena yang bertanggung jawab kepada rakyat dalam konteks ini DPR sebagai lembaga yang merupakan representasi dari kedaulatan rakyat. ${ }^{2}$ DPR merupakan salah satu lembaga tinggi negara yang sangat penting di Indoneia, di samping perangkat kenegaraan lain yang melaksanakan sistem demokrasi. ${ }^{3}$

Dalam proses pembentukannya, pada awalnya hanya 5 (lima) fraksi yang menempatkan perwakilan di dalam Pansus. Dalam perkembangannya anggota Pansus Hak Angket KPK berasal dari 7 Fraksi dengan total perwakilan sebanyak 23 anggota. Meskipun sudah disahkan, keberadaan Pansus Hak Angket KPK menuai banyak kritik dari berbagai kalangan masyarakat. Kecurigaan akan adanya konflik kepentingan (conflict of interest) pun mengemuka, karena latar belakang usulan Hak Angket tersebut adalah mendesak KPK agar membuka rekaman pemeriksaan Miryam Haryani, anggota DPR yang menjadi tersangka karena telah memberikan keterangan palsu dalam kasus korupsi E-KTP. ${ }^{4}$

Komisi III DPR menggulirkan hak angket terhadap KPK untuk mendesak membuka berita acara pemeriksaan (BAP) Miryam Haryani di kasus e-KTP. Usulan itu harus

1 Charity, M.L. (2017). Implikasi Hak Angket Dewan Perwakilan Rakyat Republik Indonesia Terhadap Komisi Pemberantasan Korupsi. Jurnal Legislasi Indonesia, 14(03): 245-254 h.246.

2 Rauf, M. A. A., Bunga, M., \& Djanggih, H. (2018). Hak Recall Partai Politik Terhadap Status Keanggotaan Dewan Perwakilan Rakyat dalam Sistem Ketatanegaraan Indonesia. Jurnal Magister Hukum Udayana (Udayana Master Law Journal), 7(4): 443-455 DOI: 10.24843/JMHU.2018.v07.i04.p03, h.447.

3 Solihah, R., \& Witianti, S. (2016). Pelaksanaan Fungsi Legislasi Dewan Perwakilan Rakyat Pasca Pemilu 2014: Permasalahan Dan Upaya Mengatasinya. Jurnal Cosmogov, 2(2): 291-307 DOI: https://doi.org/10.24198/cosmogov.v2i2.10010, h.294.

4 Kusuma, Y. P. (2017). Propaganda Hak Angket DPR terhadap KPK (Analisis Propaganda dan Komunikasi Politik). LONTAR: Jurnal Ilmu Komunikasi,5(1). DOI: http://dx.doi.org/10.30656/lontar.v5i1.486, h.41-42. 
melewati sejumlah syarat dan tahapan sebelum bisa diwujudkan menjadi panitia khusus (Pansus) hak angket.

DPR RI menilai, pembentukan Pansus Hak Angket terhadap Komisi Pemberantasan Korupsi (KPK) tidak menyalahi peraturan. Yusril Ihsa Mahendra, mantan menteri kehakiman yang sekaligus pakar hukum tata negara menilai pembentukan pansus angket telah sesuai konstitusi dan menjadi kewenangan DPR untuk mengawasi pelaksanaan perundang-undangan. Salah satunya kewenangan pengawasan terhadap $\mathrm{KPK}$, lembaga yang terbentuk melalui perundang-undangan. ${ }^{5}$

Pandangan di atas ternyata sangat berbeda dengan pendapat mantan ketua Mahkamah Konstitusi (MK), Mahfud $\mathrm{MD}^{6}$ yang menjelaskan bahwa hak angket menurut UU MD3 digunakan untuk menyelidiki pelaksanaan undang-undang atau kebijakan pemerintah. Sementara, KPK bukanlah pemerintah. Menurut penjelasan Pasal 79 ayat (3), UU MD3, lembaga yang bisa diangket oleh DPR adalah pemerintah dan lembaga pemerintah non-kementerian, KPK bukan pemerintah. Dengan demikian, pengawasan yang diusung Panitia Khusus (Pansus) Hak Angket terhadap KPK tidak tepat.

Mahfud MD menegaskan hak angket oleh Dewan dapat bersinggungan dengan pemerintah dan lembaga pembuat kebijakan. Selanjutnya KPK bukan pemerintah. Alasannya bahwa KPK menjalankan fungsi yudikatif yang memiliki kekuasaan kehakiman. Pernyataan Mahfud MD bersesuaian dengan Undang-Undang Nomor 48 Tahun 2009 tentang Kekuasaan Kehakiman. Pasal 38 ayat (2) disebutkan bahwa penyelidikan, penyidikan, dan penuntutan terkait dengan kekuasaan kehakiman.

Dalam Penjelasan atas Pasal 79 ayat (3) UU MD3, disebutkan, pelaksanaan suatu undang-undang dan/atau kebijakan pemerintah dapat berupa kebijakan yang dilaksanakan sendiri oleh Presiden, Wakil Presiden, Menteri Negara, Panglima TNI, Kapolri, Jaksa Agung, atau pimpinan lembaga pemerintah non-kementerian.

Atas dasar itu, Mahfud mengatakan DPR tidak bisa mengenakan hak angket terhadap KPK, karena KPK bukan lembaga pemerintah, sehingga KPK tidak bisa dijadikan subjek yang dikenakan hak angket. ${ }^{7}$ Dengan kata lain hak angket merupakan salah satu hak kontrol DPR terhadap kebijakan eksekutif. 8

5 Yusril Ihsa Mahendra. Adu Argument Keabsahan Pansus Angket Kpk. Available from https://www.cnnindonesia.com/nasional/20170712100351-20-227284/adu-argumenkeabsahan-pansus-angket-kpk. (diakses 18 Oktober 2017).

6 Mahfud MD. DPR Tak Bisa Awasi KPK Lewat Hak Angket. Available from https://nasional.tempo.co/read/892450/mahfud-md-dpr-tak-bisa-awasi-kpk-lewat-hakangket/ full\&view $=$ ok. (diakses 18 Oktober 2017).

7 Mahfud MD. KPK Tak Bisa Jadi Subyek untuk Hak Angket. Available from https://nasional.kompas.com/read/2017/05/02/17223461/mahfud.md.kpk.tak.bisa.jadi.su byek.untuk.hak.angket. (diakses tgl 18 Oktober 2017).

8 Iskandar, A. (2018). Analisis Hak Angket Dewan Perwakilan Rakyat DaerahKota Bandar Lampung Terhadap Kebijakan Walikota Bandar Lampung. Jurnal Keadilan Progresif, 9 (1), h. 32. Lihat juga pembahasan mengenai fungsi kontrol cabang kekuasaan legislatif (DPR) pada Asshidddiqie, Jimly, (2009), Pengantar Ilmu Hukum Tata Negara, Jakarta: PT. RajaGrafindo Persada, Jakarta, h.301-304. 
KPK adalah lembaga negara yang bisa diawasi dengan tidak menggulirkan hak angket oleh Dewan. Pengawasan terhadap KPK dapat dilakukan dengan melibatkan beberapa lembaga lain. Jika KPK melakukan pelanggaran pidana maka bisa dibawa ke pengadilan, dan jika masalah keuangan maka ke Badan Pemeriksa Keuangan (BPK).

Aturan mengenai hak angket dimuat dalam Undang Undang Nomor 17 Tahun 2014 tentang MPR, DPR, DPRD, dan DPD (UU MD3). Sesuai Pasal 79 ayat (3), hak angket adalah hak DPR untuk melakukan penyelidikan terhadap pelaksanaan suatu undangundang dan/atau kebijakan Pemerintah yang berkaitan dengan hal penting, strategis, dan berdampak luas pada kehidupan bermasyarakat, berbangsa, dan bernegara yang diduga bertentangan dengan peraturan perundang-undangan.

Syarat dan tahapan pengajuan hak angket DPR diatur lebih rinci di dalam Pasal 199 UU MD3 sebagai berikut:

(1) Hak angket sebagaimana dimaksud dalam Pasal 79 ayat (1) huruf b diusulkan oleh paling sedikit 25 (dua puluh lima) orang anggota DPR dan lebih dari 1 (satu) fraksi.

(2) Pengusulan hak angket sebagaimana dimaksud pada ayat (1) disertai dengan dokumen yang memuat paling sedikit:

a. materi kebijakan dan/atau pelaksanaan undang-undang yang akan diselidiki; dan

b. alasan penyelidikan

(3) Usul sebagaimana dimaksud pada ayat (1) menjadi hak angket DPR apabila mendapat persetujuan dari rapat paripurna DPR yang dihadiri lebih dari 1/2 (satu per dua) jumlah anggota DPR dan keputusan diambil dengan persetujuan lebih dari 1/2 (satu per dua) jumlah anggota DPR yang hadir.

Legitimasi hak angket DPR RI terhadap KPK merupakan fenomena yang menimbulkan ketidakpastian hukum. Penulis beranggapan bahwa pentingnya penelitian ini dilakukan, karena hukum harus mampu menyelesaikan segala persoalan hukum yang terjadi.

\section{Metode Penelitian}

Penelitian ini menggunakan penelitian yuridis normatif yang dilakukan dengan cara membahas doktrin-doktrin atau asas-asas dalam ilmu hukum yang berkaitan dengan topik kajian. ${ }^{9}$ Adapun pendekatan penelitian yang digunakan adalah pendekatan perundang-undangan (statute approach), dan pendekatan konseptual (conceptual aproach). Sumber bahan hukum dari penelitian ini dilakukan dengan cara inventarisasi bahan hukum primer, sekunder, dan tersier. Metode analisis bahan hukum secara deskriptif kualitatif. Prosedur pengumpulan bahan hukum dalam penelitian ini yakni terhadap bahan hukum primer, sekunder dan tersier akan diinventarisasi dan diklasifikasikan sesuai dengan masalah yang dikaji. Untuk tujuan tersebut maka terhadap bahan hukum yang berhubungan dengan permasalahan yang akan dibahas, akan dipaparkan, disistematisasi, kemudian diinterpretasikan.

${ }^{9}$ Ali, Zainuddin, (2011), Metode Penelitian Hukum, Jakarta: Sinar Grafika, h.24. 


\section{Hasil dan Pembahasan}

\subsection{Hak Angket DPR dalam Sistem Ketatanegaraan Indonesia}

Sesuai dengan konsep trias politica dalam UUD NRI Tahun 1945 jelas tergambar bahwa dalam rangka fungsi legislasi, anggaran dan pengawasan, lembaga utamanya adalah DPR sebagai lembaga representatif rakyat, sehingga dalam rangka menjalankan kewenangannya harus berdasarkan dengan ketentuan sebagaimana yang diatur dalam UUD NRI Tahun 1945 maupun dalam undang-undang Nomor 17 Tahun 2014 tentang Majelis Permusyawaratan Rakyat, Dewan Perwakilan Rakyat, Dewan Perwakilan Daerah, dan Dewan Perwakilan Rakyat Daerah (UU MD3).

Untuk melaksanakan fungsi DPR, dibarengi dengan beberapa hak yang tergambarkan dalam Pasal 20A ayat (2) UUD 1945 menjelaskan bahwa "Dalam melaksanakan fungsinya, selain hak yang diatur dalam pasal-pasal lain Undang-Undang Dasar ini, DPR mempunyai hak interpelasi, hak angket, dan hak menyatakan pendapat". Artinya bahwa DPR dalm fungsi menjalankan hak angket merupakan hak yang sangat luar biasa dalam melaksanakan fungsinya untuk menyelidiki tindakan pemerintah yang dianggap menyimpang atau pelaksanaan kebijakannya di luar dari ketentuan peraturan perundang-undangan.

\subsection{Sebab Timbulnya Hak Angket}

Pasal 79 ayat (3) UU MD3 memberi penekanan bahwa hak angket adalah hak DPR untuk melakukan penyelidikan terhadap pelaksanaan Undang-Undang dan/atau kebijakan pemerintah. Dengan demikian hak angket dikenakan pada kebijakan pemerintah atau pelaksanaan undang-undang oleh pemerintah.

Undang-Undang ini membatasinya dengan menambahkan ketentuan bahwa kebijakan atau pelaksanaan Undang-Undang yang dilakukan memiliki hubungan ataupun keterkaitan terhadap hal penting, strategis dan berdampak luas pada kehidupan masyarakat. Kemudian terdapat kemungkinan terjadinya pelanggaran terhadap peraturan perundang-undangan. Alasan yang memungkinkan diadakannya hak angket adalah mengenai syarat kebijakan ataupun pelaksanaan perundangundangan tersebut berkaitan dengan hal penting, strategis dan berdampak luas. Tidak ada batasan seberapa penting kebijakan tersebut, mengenai tolok ukur dapat tidaknya suatu kebijakan dikenakan Hak Angket. Hal yang dapat dijadikan pegangan mengenai alasan untuk mengajukan hak angket harus memenuhi seluruh unsur-unsur berikut:

a) Jika ada pelaksanaan suatu UU dan/atau kebijakan pemerintah,

b) yang berkaitan dengan hal penting, strategis, dan

c) berdampak luas pada kehidupan bermasyarakat, berbangsa, dan bernegara,

d) yang diduga bertentangan dengan peraturan perundang-undangan.

\subsection{Mekanisme Pembentukan Pansus Angket}

Pembentukan Pansus angket diatur pada Pasal 199 Undang-Undang Nomor 17 Tahun 2014 tentang MD3, menyebutkan bahwa: 
"Pengajuan Hak Angket harus diusulkan oleh paling sedikit dua puluh lima orang anggota serta lebih dari satu fraksi disertai dengan dokumen yang memuat sekurangkurangnya materi kebijakan dan/atau pelaksanaan undang-undang yang akan diselidiki dan alasan penyelidikannya. Usul hak angket juga harus mendapat perestujuan dari rapat paripurna Dewan Perwakilan Rakyat yang dihadiri lebih dari 1/2 jumlah anggota Dewan Perwakilan Rakyat dan keputusan diambil dengan persetujuan lebih dari $1 / 2$ jumlah anggota Dewan Perwakilan Rakyat yang hadir".

Menurut Pasal 201 ayat (1) UU MD3, pansus hak angket harus terdiri atas semua fraksi yang ada di dalam DPR.

Dalam isu yang dibahas ini, Pansus Hak Angket DPR terhadap KPK hanyalah diikuti enam dari total sepuluh fraksi. Bahkan perkembangan terakhir hanya menyisakan empat fraksi karena dua fraksi yaitu, Golkar dan Nasdem menarik diri. Sehingga Pansus hak angket tidak memenuhi prosedural sesuai apa yang disebutkan dalam pasal 201 UU MD3, sebab pengajuan Hak Angket DPR terhadap KPK tidak mendapat persetujuan dari semua fraksi yang ada dalam DPR.

Untuk memperbaiki praktik ketatanegaraan ke depan, anggota DPR yang akan menggunakan hak angket perlu mengubah cara yang ditempuh selama ini. Salah satu caranya, mengelaborasi secara mendalam tentang makna "kebijakan pemerintah yang penting dan strategis serta berdampak luas pada kehidupan bermasyarakat dan bernegara yang diduga bertentangan dengan peraturan perundang-undangan". Kalau itu bisa dilakukan, upaya setiap pengusul hak angket akan semakin mendapai tempat di mata publik. ${ }^{10}$

Pengertian penyelidikan yang dimaksud dengan hak angket tidak dapat disamakan secara keseluruhan dengan penyelidikan dalam KUHAP. Hal mengenai tindakan paksa seperti penangkapan, menyuruh berhenti, mengambil sidik jari, dan memotret orang dan membawa serta menghadapkan orang pada penyidik, tentunya DPR tidak berwenang untuk melakukannya.

Ketika dugaan terjadinya pelanggaran hukum dan/atau penyalahgunaan kewenangan, maka hak angket dapat dilakukan, akan tetapi temuan yang ada bukan untuk melakukan tindakan hukum (pro justitia). Hal tersebut merupakan tindakan ketatanegaraan, seperti meminta pertanggungjawaban presiden dan/atau wakil presiden (impeachment), atau untuk merumuskan kebijakan (merevisi atau membentuk UU). Jika ditemukan adanya pelanggaran hukum (dugaan tindak pidana), dapat diteruskan kepada lembaga penegak hukum. Hanya pejabat penyidik, baik KPK, Kepolisian, Kejaksaan, atau PPNS secara hukum melakukan penyelidikan (opsporing) dan penyidikan (nasporing) untuk membuktikan telah terjadi suatu tindak pidana. Secara hukum, seandainya mengandung kebenaran, akan tetapi segala temuan DPR tidak dapat dijadikan bukti telah terjadi tindak pidana. ${ }^{11}$

10 Subardjo, (2016), Penggunaan Hak Angket oleh DPR RI dalam Mengawasi Kebijakan Pemerintah. Jurnal Hukum Novelty, 7(1): 71-82 DOI: http://dx.doi.org/10.26555/novelty.v7i3.a3935. 7(1), h. 79

11 Naswar, N. (2012), Hak Angket Dalam Konstelasi Ketatanegaraan Indonesia, Jurnal Konstitusi, 1(1): 1-13, h.7 
Meskipun demikian dalam meyelenggarakan hak angket terdapat beberapa hak dan kewenangan yang dapat dilakukan oleh DPR dalam melakukan penyelidikan yaitu:

a) Meminta keterangan pada pemerintah, badan hukum, organisasi, profesi saksi, pakar dan/atau pihak terkait

1. Saksi dapat merupakan warga negara Indonesia maupun warga negara asing yang ada di Indonesia,

2. Mendapatkan keterangan dari saksi atau ahli yang berada diluar negeri melalui pertanyaan secara tertulis kepada menteri yang bersangkutan yang membantu dipenuhinya pertanyaan-pertanyaan itu dengan perwakilan Indonesia di luar negeri,

3. Dalam melakukan pemanggilan DPR dapat melakukannya secara tertulis

b) Melakukan sumpah pada saksi atau ahli yang berumur di atas 16 tahun

c) Melakukan penuntutan pada saksi atau ahli yang lalai, melalui Kejaksaan Pengadilan Negeri

d) Memaksa saksi atau ahli untuk datang memenuhi panggilan dengan bantuan Kepolisian atau Kejaksaan

e) Melakukan penahanan kepada saksi ahli yang membangkang melalui ketua Pengadilan Negeri

f) Memeriksa surat-surat yang disimpan oleh pegawai kementerian

g) Melakukan penyitaan dan atau menyalin surat kecuali berisi rahasia negara melalui Pengadilan Negeri.

Dengan demikian hak dan kewenangan yang dimiliki oleh DPR adalah hak untuk melakukan evaluasi pelaksanaan tugas pemerintah atau penyelenggara negara dalam hal ini adalah kekuasaan eksekutif,dan bukan untuk penegakan hukum.

Ketentuan mengenai hal apa yang menjadi objek penyelidikan dapat ditemukan pada Pasal 79 ayat (3) Undang-Undang Nomor 17 Tahun 2014 yaitu:

1. Berkaitan dengan pelaksanaan undang-undang dan/atau kebijakan pemerintah,

2. Berkaitan dengan hal penting, strategis dan berdampak luas pada kehidupan masyarakat, berbangsa dan bernegara,

3. Diduga bertentangan dengan peraturan perundang-undangan.

Objek Angket yang dilakukan oleh DPR adalah kebijakan atau pelaksanaan UndangUndang oleh pemerintah yang masuk dalam ranah kekuasaan eksekutif. Ketentuan tersebut juga pada pokoknya mengatur bahwa penggunaan hak angket DPR pada dasarnya merupakan hak kelembagaan DPR yang diberikan oleh undang-undang.

Penjelasan Pasal 79 ayat (3) UU MD3 telah mengaburkan esensi hak angket sebagai wujud hubungan antar lembaga negara yang berlangsung pada tingkat ketatanegaraan Indonesia. Penjelasan tersebut telah menarik badan-badan dan/atau jabatan pemerintah di bawah Presiden ke dalam ranah jangkauan hak angket oleh DPR. Padahal, konsekuensi dari sistem pemerintahan Presidensial semestinya menempatkan hak angket DPR hanya untuk ditujukan kepada Presiden sebagai kepala pemerintahan. Secara substantif, hak angket ditujukan kepada pelaksanaan UU dan/atau kebijakan pemerintah, yang jika dicermati merupakan bagian dari pelaksanaan kekuasaan eksekutif yang dilakukan oleh Presiden, Wakil Presiden, Kepolisian RI, Tentara Nasional RI, Kejaksaan Agung, dan/atau lembaga non 
kementerian. Sehingga tidak tepat jika ditujukan pada KPK yang merupakan lembaga independen. ${ }^{12}$

Rumusan alternatif komulatif dari ketentuan Pasal 79 ayat (3) dari UU MD3 sama sekali tidak dapat dijadikan sebagai dasar untuk menjadikan KPK sebagai subjek hukum yang dapat diselidiki oleh DPR. Tafsiran norma ${ }^{13}$ tersebut adalah hanya lembaga yang berada di bawah ranah eksekutif (yang bertanggung jawab langsung kepada presiden) yang dapat dilakukan hak angket.

\subsection{Hak Angket DPR Terhadap KPK}

Pelaksanaan hak angket DPR terhadap KPK merupakan suatu pelaksanaan yang akan menjadikan KPK sebagai lembaga yang bertaring tapi tak mampu mengigit, sebab KPK lahir sebagai anak kandung dari reformasi yang mencoba melepaskan pengaruh dari kekuasaan manapun baik kekuasaan eksekutif, kekuasaan yudikatif maupun kekuasaan legislatif. Sehingga dengan adanya hak angket DPR terhadap KPK, KPK secara tidak langsung dimasuki oleh kekuasaan legislatif yang syarat akan permainan politik dan tidak sesuai lagi dengan dasar pembentukan KPK yaitu lembaga yang bebas dari pengaruh kekuasaan manapun (Independen).

Dalam Pasal 6 Undang-Undang KPK disebutkan bahwa Komisi Pemberantasan Korupsi mempunyai tugas:

a) Koordinasi dengan instansi yang berwenang melakukan pemberantasan tindak pidana korupsi,

b) Supervisi terhadap instansi yang berwenang melakukan pemberantasan tindak pidana korupsi,

c) Melakukan penyelidikan, penyidikan dan penuntutan terhadap tindak pidana korupsi,

d) Melakukan tindakan-tindakan pencegahan tindak pidana korupsi,

e) Melakukan monitor terhadap penyelenggara pemerintahan negara.

Tugas KPK sebagaimana tercantum di dalam Pasal 6 huruf c Undang-Undang Nomor 30 Tahun 2002 Tentang Komisi Pemberantasan Tindak Pidana Korupsi yaitu melakukan penyelidikan, penyidikan dan penuntutan terhadap tindak pidana korupsi. Dengan itu adanya hak DPR untuk mengangket KPK maka secara tidak langsung KPK bisa saja diintervensi ataupun mengganggu proses penegakan hukum, karena hak angket adalah hak menyelidiki, dan tidak menutup kemungkinan ketika KPK mentersangkakan pelaku tindak pidana korupsi dan DPR menganggap bahwa proses penetapan tersangka tidak sesuai dengan apa yang menjadi aturan KPK, maka dengan opini politik DPR dapat dan kapan saja mengambil alih peran dan atau mengangket

12. Zihan Syahayani, (2017), Meninjau Ulang Hak Angket KPK, Jurnal Update Indonesia, X(5), h.7-8

13 Persoalan tafsir norma amat berkaitan dengan rumusan bahasa hukum dalam proses perumusan norma perundang-undangan guna menghindari tafsir dengan alasan kekaburan makna. Lihat pembahasan ini dalam Nurul Qamar \& Hardianto Djanggih (2017). Peranan Bahasa Hukum dalam Perumusan Norma Perundang-undangan. Jurnal Ilmiah Kebijakan Hukum, 11(3); h.346. 
KPK berdasarkan dalih bahwa KPK tidak berdasar pada peraturan perundangundangan, oleh karena itu dapat diangket.

Pelaksanaan hak angket DPR terhadap KPK juga dapat menimbulkan kerancuan ketatanegaraan. Perumusan kehadiran KPK dalam sistem ketatanegaraan Indonesia sesuai dengan Pasal 3 UU KPK yang menegaskan bahwa "Komisi Pemberantasan Korupsi adalah lembaga negara yang dalam melaksanakan tugas dan kewenangannya bersifat independen dan bebas dari kekuasaan manapun". Dalam ketentuan ini, yang dimaksud dengan "kekuasaan manapun" adalah kekuatan yang dapat mempengaruhi tugas dan wewenang KPK atau komisi secara individual dari pihak eksekutif, yudikatif, legislatif, pihak-pihak lain yang terkait dengan perkara tindak pidana korupsi, atau keadaan dan situasi ataupun dengan alasan apapun. ${ }^{14}$

Upaya melihat KPK sebagai lembaga eksekutif dalam melaksanakan fungsi dan kewenangannya adalah keliru dengan tanpa melihat bahwa dalam perkembangan ketatanegaraan doktrin trias politica berkembang secara pesat dan tiga cabang kekuasaan tersebut antara kekuasaan eksekutif, legislatif dan yudikatif adalah ajaran klasik, sehingga kemunculan suatu lembaga-lembaga atau komisi merupakan bentuk perkembangan ketatanegaran dalam hal ini KPK dapat dikatakan konsep cabang kekuasaan di luar dari doktrin cabang kekuasaan klasik, sedangkan hadirnya suatu lembaga KPK adalah bentuk respon terhadap korupsi yang makin hari semakin meningkat.

Keseriusan dalam merespon korupsi ditandai dengan hadirnya beberapa peraturan perundang-undangan, antara lain:

a) Undang-Undang Nomor 28 tahun 1998 Tentang Penyelenggara Negara yang Bersih dan Bebas dari Korupsi, Kolusi, dan Nepotisme

b) Undang-Undang Nomor 31 Tahun 1999 jo Undang-Undang Nomor 20 Tahun 2001 tentang Pemberantasan Tindak Pidana Korupsi

c) Peraturan Pemerintah Nomor 71 Tahun 2000 Tentang Tata Cara Pelaksanaan Peran Serta Masyarakat dan Pemberian Penghargaan Dalam Pencegahan dan Pemberantasan Tindak Pidana Korupsi

d) Undang-Undang Nomor 15 jo Undang-Undang Nomor 25 Tahun 2003 Tentang Tindak Pidana Pencucian Uang

e) Undang-Undang Nomor 30 Tahun 2002 Tentang Komisi Pemberantasan Tindak Pidana Korupsi.

Berdasarkan beberapa peraturan tersebut di atas jelas tergambar bahwa upaya dalam rangka memberantas tindak pidana korupsi harus dengan lembaga yang bersifat independen dan bebas dari kekuasaan manapun yang tergambar dalam ketentuan Pasal 3 UU KPK. Sehingga Hak angket DPR terhadap KPK dapat menjadi bumerang dalam rangka pemberantasan korupsi dan dapat menjadi penghambat pemberantasan tindak pidana korupsi, sebab DPR adalah suatu lembaga perwakilan yang terdiri dari beberapa golongan partai politik yang masing-masing membawa kepentingan, bahkan bisa saja kepentingan itu dibawa ke KPK yaitu kepentingan penyelidikan, penyidikan dan penuntutan pada akhirnya sifat dari independensi KPK dapat diruntuhkan dengan masuknya kekuasaan legislatif dalam hal ini adalah DPR.

14 Penjelasan Pasal 3 UU. KPK. 


\subsection{Putusan Mahkamah Konstitusi}

Mahkamah Konstitusi (MK) dalam Putusannya pada perkara Nomor 36 dan 37/PUUXV/2017 memberikan pertimbangan hukum bahwa keberadaan KPK untuk menjalankan tugas kepolisian dan kejaksaan dalam hal penyelidikan, penyidikan, dan penuntutan tindak pidana korupsi, dimana eksistensi kepolisian dan kejaksaan tidak mendapatkan kepercayaan publik karena dianggap belum optimal dalam pemberantasan tindak pidana korupsi. Konstruksi hukumnya menurut hakim MK bahwa tugas ketiga lembaga tersebut berada di ranah lembaga eksekutif yang menjalankan fungsi eksekutif. Oleh karenanya, KPK dapat dijadikan objek hak angket DPR dalam fungsi pengawasan. ${ }^{15} \mathrm{KPK}$ bukan di ranah yudikatif, karena bukan badan peradilan yang berwenang memeriksa, mengadili dan memutus perkara. KPK juga bukan badan legislatif, karena bukan lembaga yang membentuk undang-undang.

Putusan Mahkamah Konstitusi Nomor 36/PUU-XV/2017 tepatnya pada awal Februari 2018 yang mengabulkan gugatan DPR dalam perkara pengujian konstitusionalitas Pasal 79 ayat (3) Undang-Undang Nomor 17 Tahun 2014 Tentang MD3 telah menambah perdebatan panjang terkait pelembagaan KPK itu sendiri. Sebagai sebuah mahkamah yang bertugas mengawal dan bertindak selaku penafsir akhir konstitusi (the Guardian and the Interpreter of the Constitution), putusan Mahkamah Konstitusi sebagaimana ketentuan dalam UUD NRI Tahun 1945 Pasal 24C ayat (1) adalah bersifat final dan mengikat sehingga meskipun menuai pro dan kontra dari berbagai pihak dalam putusannya terkait dengan objek hak angket DPR yang berdampak pada posisi kelembagaan KPK. Dengan putusan Mahkamah Konstitusi ini, maka KPK merupakan lembaga yang berada di ranah eksekutif, bersama-sama dengan Kepolisian dan Kejaksaan, sehingga KPK bagian dari eksekutif yang bertugas melakukan penyelidikan, penyidikan dan penuntutan.

Pasal 6 UU KPK memberi hak kepada KPK untuk melakukan koordinasi dan supervisi terhadap instansi yang berwenang melakukan pemberantasan tindak pidana korupsi. Sehingganya KPK bukan menjadi bagian eksekutif yang ditafsirkan bahwa Kepolisian dan Kejaksaan fungsi dan kewenangannya sama dengan KPK. Dalam sistem pemerintahan presidential sebagaimana ajaran Montesquieu, yakni trias pilitica atau pemisahan kekuasaan (separation of power) bahwa prinsip demokrasi harus terdapat pemisahan kekuasaan yang terdiri atas eksekutif, legislatif dan yudikatif untuk menghindari kekuasaan yang absolut atau terpusat. ${ }^{16}$ Oleh karena itu, pengawasan dan keseimbangan (checks and balances) kehadiran suatu lembaga negara manapun tetap harus diawasi guna mencapai keseimbangan jalannya suatu pemerintahan.

Hal tersebut, jika dikaitkan pada amar putusan MK Nomor 36/PUU-XV/2017 meletakkan KPK sebagai eksekutif dan dapat diangket oleh DPR. Kemudian Mahkamah Konstitusi tidak memberi batasan apa saja yang menjadi objek angket terhadap KPK, sehingga putusan Mahkamah Konstitusi ini memberi implikasi hukum

15 Novianti, (2018), Implikasi Putusan MK Atas Penggunaan Hak Angket DPR Terhadap KPK, Jurnal Info Singkat, X(04), h. 2.

16 Charity, M.L. (2017), Op.Cit, h.246. 
terhadap KPK sebagai lembaga independen yang bebas dari pengaruh kekuasaan manapun.

Secara teoretik kewenangan mengawasi yang dimiliki oleh DPR, setidaknya dapat dirinci enam hal, yang meliputi sebagai berikut:

a) Pengawasan terhadap penentuan kebijakan (control of policy making)

b) Pengawasan terhadap pelaksanaan kebijakan (control of policy execiting)

c) Pengawasan terhadap penganggaran dan belanja negara (control of budgeting)

d) Pengawasan terhadap pelaksanaan anggaran dan belanja negara (control of budget implementation)

e) Pelaksanaan terhadap kinerja pemerintahan (control of government performances)

f) Pengawasan terhadap pengangkatan pejabat publik (control of political appointment of public officials).

Berdasarkan kewenangan mengawasi yang dimiliki oleh DPR di atas, seharusnya Putusan Mahkamah Konstitusi ini memberi batasan angket, sebab angket ini adalah bagaian dari pengawasan yang dimiliki oleh DPR. Karena yang di angket DPR adalah KPK, dimana tugas dan fungsi KPK adalah pemeberantasan tindak pidana korupsi, sehingga jika tidak diberi batasan maka dapat saja angket ini meluas pada ranah penegakan hukum KPK untuk memberantas tindak pidana korupsi.

Hak angket yang dimiliki DPR adalah hak menyelidiki yang bertalian dengan pemerintahan dan/atau penyelenggara Negara, bukan penegakan hukum. Tidak adanya batasan hak angket DPR kepada KPK melalui putusan Mahkamah Konstitusi Nomor 36/PUU-XV/2017 dapat dan bisa saja terimplikasi pada penegakan hukum yang dilakukan oleh KPK. KPK adalah lembaga negara yang dalam melaksanakan tugas dan wewenangnya bersifat independen dan bebas dari pengaruh kekuasaan manapun (Pasal 3 UU Nomor 30 Tahun 2002). Tujuan dibentuknya KPK tidak lain adalah meningkatkan daya guna dan hasil guna terhadap upaya pemberantasan tindak pidana korupsi. ${ }^{17}$

Seharusnya Mahkamah Konstitusi dalam melakukan putusannya menitikberatkan KPK pada kedudukan dan fungsinya sebagai lembaga yang tetap independen agar dapat menjadi kekuatan bagi KPK dalam menjalankan tugas dan wewenang memberantas tindak pidana korupsi. Hambatan penanganan tindak pidana korupsi karena campur tangan dari pihak eksternal misalnya eksekutif, yudikatif, atau legislatif. ${ }^{18}$

Akan tetapi posisi KPK yang berada di ranah eksekutif dan ditetapkan menjadi subjek dan objek hak angket sebagai bagian dari pelaksanaan fungsi pengawasan DPR berdasarkan putusan Mahkamah Konstitusi Nomor 36/PUU-XV/2017 tidak memberi penguatan dasar hukum kelembagaan dan karakteristik sebagai lembaga negara yang independen. Lebih jauh lagi, hal ini bukan hanya berimplikasi terhadap kelembagaan,

17 Sugiarto, T. (2013), Peranan Komisi Pemberantasan Korupsi (KPK) Dalam Pemberantasan Tindak Pidana Korupsi Di Indonesia, Jurnal Cakrawala Hukum, 18(2): 188-196, h.188.

18 Nugroho, H. (2013), Efektivitas Fungsi Koordinasi Dan Supervisi Dalam Penyidikan Tindak Pidana Korupsi Oleh Komisi Pemberantasan Korupsi, Jurnal Dinamika Hukum, 13(3): 392-401 DOI: http://dx.doi.org/10.20884/1.jdh.2013.13.3.245, h. 396. 
tetapi juga terhadap kewenangan, akuntabilitas serta integritasnya. Perlu dipahami bahwa independensi suatu lembaga negara yang kuat, tanpa kewenangan yang kuat tidak akan membuat KPK berjalan efektif dalam menjalankan tugasnya. Oleh karena itu putusan Mahkamah Konstitusi Nomor 36/PUU-XV/2017 memberi implikasi pada kedudukan KPK sebagai lembaga negara yang dalam melaksanakan tugas dan wewenangnya bersifat independen dan bebas dari pengaruh kekuasaan manapun, sesuai bunyi Pasal 3 UU KPK.

\section{Kesimpulan}

Legitimasi hak angket Dewan Perwakilan Rakyat Republik Indonesia terhadap Komisi Pemberantasan Korupsi tidak hanya berdasarkan putusan Mahkamah Konstitusi Nomor 36/PUU-XV/2017, namun harus memenuhi unsur-unsur sebagaimana Pasal 79 ayat (3), Pasal 199, dan Pasal 201 ayat (2) Undang-Undang Nomor 17 Tahun 2014 Tentang MD3. Artikel ini merekomendasikan perlunya berbagai upaya penguatan terhadap eksistensi Komisi Pemberantasan Korupsi sebagai lembaga yang independen, serta bebas dari pengaruh kekuasaan manapun, mengingat keberadaan KPK sangat penting bagi Negara Indonesia dengan tingkat korupsi yang masih tinggi.

\section{Ucapan terima Kasih}

Ucapan terima kasih dan penghargaan setinggi-tingginya kepada Dekan Fakultas Hukum Unievrsitas Muslim Indonesia, atas motivasi dan kesempatan kepada penulis sehingga dapat menyelesaikan karya tulis ilmiah ini, guna untuk memenuhi kewajiban Tri Dharma Perguruan Tinggi di bidang Penelitian.

\section{DAFTAR PUSTAKA}

\section{$\underline{\text { Buku }}$}

Asshidddiqie, Jimly, (2009), Pengantar Ilmu Hukum Tata Negara, Jakarta: PT. RajaGrafindo Persada, Jakarta.

Ali, Zainuddin, (2011), Metode Penelitian Hukum, Jakarta: Sinar Grafika.

\section{Jurnal}

Iskandar, A. (2018). Analisis Hak Angket Dewan Perwakilan Rakyat DaerahKota Bandar Lampung Terhadap Kebijakan Walikota Bandar Lampung. Jurnal Keadilan Progresif, 9 (1), h. 32.

Nugroho, H. (2013), Efektivitas Fungsi Koordinasi Dan Supervisi Dalam Penyidikan Tindak Pidana Korupsi Oleh Komisi Pemberantasan Korupsi, Jurnal Dinamika Hukum, 13(3): 392-401 DOI: http://dx.doi.org/10.20884/1.jdh.2013.13.3.245.

Charity, M.L. (2017). Implikasi Hak Angket Dewan Perwakilan Rakyat Republik Indonesia Terhadap Komisi Pemberantasan Korupsi. Jurnal Legislasi Indonesia, 14(03): 245-254.

Naswar, N. (2012), Hak Angket Dalam Konstelasi Ketatanegaraan Indonesia, Jurnal Konstitusi, 1(1): 1-13. 
Novianti, (2018), Implikasi Putusan MK Atas Penggunaan Hak Angket DPR Terhadap KPK, Jurnal Info Singkat, X(04).

Nurul Qamar \& Hardianto Djanggih (2017). Peranan Bahasa Hukum dalam Perumusan Norma Perundang-undangan. Jurnal Ilmiah Kebijakan Hukum, 11(3); DOI: http://dx.doi.org/10.30641/kebijakan.2017.V11.337-347

Rauf, M. A. A., Bunga, M., \& Djanggih, H. (2018). Hak Recall Partai Politik Terhadap Status Keanggotaan Dewan Perwakilan Rakyat dalam Sistem Ketatanegaraan Indonesia. Jurnal Magister Hukum Udayana (Udayana Master Law Journal), 7(4): 443455 DOI: 10.24843/JMHU.2018.v07.i04.p03.

Solihah, R., \& Witianti, S. (2016). Pelaksanaan Fungsi Legislasi Dewan Perwakilan Rakyat Pasca Pemilu 2014: Permasalahan Dan Upaya Mengatasinya. Jurnal Cosmogov, 2(2): 291-307 DOI: https://doi.org/10.24198/cosmogov.v2i2.10010.

Subardjo, (2016), Penggunaan Hak Angket oleh DPR RI dalam Mengawasi Kebijakan Pemerintah. Jurnal Hukum Novelty, 7(1): 71-82 DOI: http://dx.doi.org/10.26555/novelty.v7i3.a3935. 7(1).

Sugiarto, T. (2013), Peranan Komisi Pemberantasan Korupsi (KPK) Dalam Pemberantasan Tindak Pidana Korupsi Di Indonesia, Jurnal Cakrawala Hukum, 18(2): 188-196.

Kusuma, Y. P. (2017). Propaganda Hak Angket DPR terhadap KPK (Analisis Propaganda dan Komunikasi Politik). LONTAR: Jurnal Ilmu Komunikasi, 5(1). DOI: http://dx.doi.org/10.30656/lontar.v5i1.486.

Zihan Syayahani, (2017), Meninjau Ulang Hak Angket KPK, Jurnal Update Indonesia, X(5): 5-10.

\section{Peraturan Perundang-undangan}

Undang-Undang Dasar Negara Republik Indonesia Tahun 1945.

Undang-Undang Nomor 30 Tahun 2002 Tentang Komisi Pembarantasan Tindak Pidana Korupsi (Lembaran Negara Republik Indonesia Tahun 2002 Nomor 137, Tambahan Lembaran Negara Republik Indonesia Nomor 4250).

Undang-Undang Republik Indonesia Nomor 17 Tahun 2014 Tentang MPR, DPR, DPRD, dan DPD (Lembaran Negara Republik Indonesia Tahun 2014 Nomor 182, Tambahan Lembaran Negara Republik Indonesia Nomor 5568).

\section{$\underline{\text { Internet }}$}

Yusril Ihsa Mahendra. Adu Argument Keabsahan Pansus Angket Kpk. Available from https://www.cnnindonesia.com/nasional/20170712100351-20-227284/aduargumen-keabsahan-pansus-angket-kpk. (diakses 18 Oktober 2017).

Mahfud MD. DPR Tak Bisa Awasi KPK Lewat Hak Angket. Available from https://nasional.tempo.co/read/892450/mahfud-md-dpr-tak-bisa-awasi-kpklewat-hak-angket/ full\&view=ok. (diakses 18 Oktober 2017).

Mahfud MD. KPK Tak Bisa Jadi Subyek untuk Hak Angket. Available from https://nasional.kompas.com/read/2017/05/02/17223461/mahfud.md.kpk.tak. bisa.jadi.subyek.untuk.hak.angket. (diakses tgl 18 Oktober 2017). 